\title{
The Effect of Financial Performance and Intellectual Capital on Firm Value with CSR as a Mediating Variable in Banking Industry
}

\author{
Hendro Lukman ${ }^{1 *}$, Helvenni Tanuwijaya ${ }^{1}$ \\ ${ }^{1}$ Faculty of Economics and Business, Universitas Tarumanagara, Jakarta - 11470, Indonesia \\ *Corresponding author.Email:hendrol@fe.untar.ac.id
}

\begin{abstract}
This study aimed to obtain empirical evidence on how firm value is influenced by intellectual capital in addition to financial performance with CSR reports as a mediating variable in the banking industry. Based on the path-analysis performed among the banks operating in Indonesia during 2016-2018, the results show that financial performance and intellectual capital have a direct and positive effect on company value, but there is no significant effect of CSR as a mediating variable. Therefore, CSR activities in banking do not strengthen the intellectual capital and profitability in increasing firm value. By the results of this research, bankings should increase their useful CSR activities so that the funds that have been spent can be more beneficial to increase the value of the company.
\end{abstract}

Keywords: Firm Value, Financial Performance, Intellectual Capital, Sustainability Reporting

\section{INTRODUCTION}

The established companies are generally aimed to improve the welfare of the owners or shareholders. For this reason, company management must make the company grow and develop into a long-lasting company. One of the ways that companies can do to achieve these goals is by increasing the company value. The high corporate value will reflect the high level of prosperity experienced by the shareholders. The value of the company will be reflected in its share price, which is the price formed by the agreement of buyers and sellers in the stock market, which reflects the company's performance from a financial and operational perspective. The higher the firm value is, the higher the share value will be.

The formation of stock prices in the market can be caused by fundamental and technical factors. Fundamental factors are generally analyzed from the financial performance as seen from the audited financial reports, while technical factors are prices that occur in the market within a certain period based on non-financial issues that occur in the company. Good financial statements provide the information that ensures the survival of the company by the availability of resources as seen in the disclosure that can explain social activities and the activities that preserve the environment as a resource [1]. This social activity is the company's social responsibility to the environment to improve the community welfare and preserve natural resources for the company's existence in the area where the company operates. This responsibility can be said to be a form of return from the resources that have been used by the company. For this reason, the government of the
Republic of Indonesia has issued Law Number 40 Year 2007 concerning Social and Environmental Responsibility, which states that companies engaged in natural resources are obliged to implement social responsibility, known as Corporate Social Responsibility (CSR) [2], which is strengthened by the Financial Services Authority (FSA) Regulation Number 51 / POJK.03 / 2017 concerning the Implementation of Sustainable Finance for Financial Service Institutions, Issuers, and Public Companies, which requires all companies in the banking industry that have listed in the market to issue Sustainability Report [3]. Thus, reports on CSR activities as a voluntary disclosure have become a mandatory disclosure. The disclosure of this activity in the financial statements can increase the image and positive value for the company [4] which can increase the investment value or company value.

To maintain the continuity of life, the company does not only maintain the availability of physical resources, however, companies must also innovate to create something new through human resource management or intellectual capital. Intellectual capital consists of human capital, organizational (structural) capital, and relational (customer) capital. There is a very important and valuable asset for companies in creating company value [5].

From previous research, the relationship between financial performance as measured by Return-on-Assets (ROA) shows that it has a positive influence on firm value [6], but on contrary to [7]. Likewise, research on the effect of intellectual capital on firm value, such as [5] conducted in Malaysia stated that intellectual capital has a positive and significant effect on firm value, which is in line with [8], but on contrary to [17]. Meanwhile, the results of [9] show 
that intellectual capital has a positive and significant effect on corporate social responsibility, which is different from the research conducted by [10]. Another research conducted [11] that examined the effect of financial performance on corporate social responsibility, showed that return-on-assets has a positive effect on corporate social responsibility, and is also in line with [12]. According to differences in the results of previous research, this study was conducted with a different research model, namely path analysis, whereas CSR activities serve as a mediating variable because financial performance can be directly or indirectly influenced by CSR activities, while intellectual capital is a social aspect of CSR which also adversely affects the company's value, either directly or indirectly.

The subject of this research is the banking companies in Indonesia. As it is known that the human capital factor in this industry becomes the main success factor, and the products of this industry come and are carried out by human beings, not by machines. Thus, this study would test empirically whether financial performance as measured by ROA and human capital as measured by intellectual capital affects firm value, either directly or through CSR activities contained in the sustainability reporting.

The purpose of this research was to find out whether financial performance and intellectual capital influence firm value and how the implementation of the CSR program can encourage financial performance and intellectual capital in increasing firm value. Thus, by the results of this study, banks can consider whether CSR activities can improve the effectiveness of financial performance and human capital on firm value.

\section{LITERATURE REVIEW}

\subsection{Stakeholder Theory}

The stakeholder theory states that a company has the goal of creating value for its stakeholders [14]. Stakeholders or interested parties are the parties who can influence or be influenced by the company either directly or indirectly [15]. Stakeholders are divided into two groups, which are internal stakeholders and external stakeholders. Internal stakeholders are those in the company such as the management, employees, and investors. External stakeholders are those outside the company, for example, the community around the company, customers, suppliers, government, non-governmental organizations, investors, creditors, and others. Stakeholders are the main element in maintaining the sustainability and success of the company [16] so that their role greatly influences the company's operations. Therefore, this theory becomes the basis for CSR activities. The role of shareholders determines the relationship with stakeholders through CSR activities. Therefore, this CSR activity report will become very important information [17].

\subsection{Resource-Based-View Theory}

Resource-based-view theory is a theory that aims to explain the capabilities of a company in the environment outside the company [18]. The meaning of the capability is if the company has special, unique, and irreplaceable resources, then this can be said to be the main key for the company to achieve success by managing its resources [19]. Every economic activity must create added-value. Added-value is measured by the availability of resources such as physical and intellectual capital, which is represented by employees and their abilities and potentials [20]. Resource-based-view theory is thinking that develops in the company's competitive advantage and strategic management theory, which believes that good and superior resources will make the company gain a competitive advantage among its competitors [21]. Good, skilled, experienced, and superior human resources are valuable intangible assets that can increase the success and value of the company, which can be assessed from financial performance.

\subsection{Signalling Theory}

The signaling theory states that a quality company must be able to provide a signal for its potential to the market so that investors and stock traders can re-evaluate the value of the company, and be taken into consideration in making decisions [22]. According to this theory, companies will try to provide a positive signal to investors through disclosure in the financial reports [22] voluntarily, such as CSR activities and Intellectual Capital [23]. Thus, the importance of disclosing complete information from the company to shareholders, that is disclosed in the financial statements, will be taken into consideration for investment decisions by investors, creditors or stock traders, or other interested parties.

\subsection{Standard Global Reporting Initiative}

Global Reporting Initiative (GRI) is an international organization that has pioneered sustainability reporting since 1997. GRI helps businesses and governments around the world understand and communicate the impact of critical sustainability issues such as human rights, climate change, governance, and social welfare so that this encourages business people to take action in creating social, environmental, and economic benefits for everyone. Therefore, this organization has developed the Global Reporting Initiative (GRI) Standard, which is the most widely-used standard for preparing sustainable reporting and represents the best practice to report various social, economic, and environmental impacts globally. This standard was first created in 2000, and it has been revised several times as the complexity of the business world grows. The last revision was done in 2016, this last generation guideline is called "4th generation" or G4. G4 consists of general standards and special standards. The 
general standard of GRI G4 is a standard that can be used by companies of various sizes, types, and industry sectors, namely GRI 101 (Foundation), GRI 102 (General Disclosures), GRI 103 (Management Approach), GRI 200 (Economic), GRI 300 (Environmental) and GRI 400 (Social), while special standards are additional standards that must be implemented for specific industries.

For the preparation of sustainable reporting based on the GRI G4 standards, there are two options, namely: 1) Core Option - This option explains that a report contains the minimum required information to understand the nature of the organization, its material topics, and impacts and how it is addressed; and 2) Comprehensive Option - The options covering strategy, ethics, organizational integrity and governance, and the organization is required to report all specific disclosures for each material topic contained in the GRI G4 standard. In this study, all the companies studied used core-options with 135 items of general GRI standards, and 33 items of specific standards for the banking industry.

\subsection{Firm Value}

The value of the company is a comprehensive picture that describes a company [24]. This value is used in measuring the level of importance of a company from various viewpoints of investors, which is accompanied by investors' assessment of the stock price [25]. In other words, the value of the company can be reflected as the price or money that must be spent to acquire the company [26]. Thus, it can be concluded that the higher the value of the company is, the higher the value of the company share will be.

\subsection{Financial Performance}

The benchmarks for business success are measured from financial performance. Financial performance is seen in the financial statements which are analyzed using measurements following the applicable regulations with specific objectives. Furthermore, financial performance is one of the components that can indicate that an organization is run with efficiency and effectiveness in achieving its objectives [27]. Efficiency is achieved if the company can minimize the input with optimal output, while effectiveness is achieved if management can determine the right tools to achieve these goals. Good financial performance will affect company value. This is supported by the research by [28]. Also, to ensure the sustainability of company resources, the CSR implementation will affect the achievement of these goals.

\subsection{Intellectual Capital}

Intellectual capital is the knowledge that can be converted into value [29], which is a combination of skills, knowledge, customer relationships, capabilities, information, databases, findings, and organizational structure [30]. Intellectual capital is useful for improving company performance, company value, and increasing the role of intangible assets, which are the characteristics of economic knowledge and information [31]. Intellectual capital is divided into three types based on economic behavior, namely relational (customer) capital, organizational (structural) capital, and human capital [32]. Relational capital describes social relationships and networks inside and outside the company [33]. Structural Capital is organizational procedures, organizational structure, strategies, patents, trademarks, databases, culture, and knowledge norms that are owned and applied by a company and are not attached to employees [33]. Human capital is described by employees who are employed in the company to achieve their targets and company targets by utilizing their skills, knowledge, education, experience, abilities, and attitudes [33]. Intellectual capital is an important element in the creation of company value, whereas the greater the coefficient is, the better the intellectual capital owned by the company will be in creating company value, which is supported by [5].

\subsection{Corporate Social Responsibility (CSR)}

Corporate social responsibility (CSR) is an organized and integrated activity between social and environmental issues related to company operations and voluntary interactions with stakeholders, which are not limited to organizational relationships, but also legal responsibility [14]. CSR is a strategy carried out by companies to create value for the company and society through interactions between the company and its stakeholders that can show a good reputation and impression for the company [34] in addition to a form of responsibility to repair environmental damage caused by the company activities [15]. So, it can be said that CSR is a social activity that is obliged to be implemented by companies to show concern toward the environment and society due to the use of their resources. Another benefit of CSR is that it can increase the trust and attention of investors to make investments.

\section{HYPOTHESES DEVELOPMENT}

Each company must be related to its stakeholders. The company will not grow and develop without a harmonious relationship with the stakeholders. The relationship between stakeholders and the company will be bridged by CSR activities [34] whereas the results of these activities are included in sustainability reporting [35]. The success of a company is generally measured by financial performance, which is a reflection of the work results and good relations between the company as an institution and its stakeholders. However, some stakeholders are directly related to the company's performance, namely internal stakeholders such as human capital as measured by intellectual capital, and indirectly, namely external stakeholders [16] such as customers. One of the financial performances presented in the financial statements is 
measured by return-on-assets. Thus, this research model attempted to obtain empirical evidence whether the effect of company performance and human capital burdens on company value is the company's performance as measured from a market point-of-view (investor) [25]. Based on [36], there is a positive effect of CSR on firm value, and this research is supported by [37]. Thus, the first hypothesis was developed as follow:

$\mathrm{H}_{1}$ : Corporate Social Responsibility has a significant and positive effect on firm value.

A study by [5] concluded that intellectual capital has a positive and significant effect on firm value, which is in line with [8]. Thus, the second hypothesis was developed as follow:

$\mathrm{H}_{2}$ : Intellectual Capital has a significant and positive effect on firm value.

The relationship between financial performance as measured by Return-on-Assets (ROA) shows that it has a positive influence on firm value [6]. Thus, the third hypothesis was developed as follow:

$\mathrm{H}_{3}$ : Financial Performance has a significant and positive effect on firm value.

Studying the relationship between intellectual capital and firm value, [9] stated that intellectual capital has a positive and significant effect on Corporate Social Responsibility Thus, the fourth hypothesis was developed as follow:

$\mathrm{H}_{4}$ : Intellectual Capital has a significant and positive effect on Corporate Social Responsibility.

A study conducted by [11] showed that financial performance measured by ROA has a positive effect on corporate social responsibility, and is also in line with [12] and [13]. Thus, the fifth hypothesis was developed as follow:

$\mathrm{H}_{5}$ : Financial performance has a significant and positive effect on corporate social responsibility.

\section{METHODS}

This research methodology is quantitative using the secondary data taken from banking companies listed on the Indonesia Stock Exchange (IDX). The period used is 2016-2018, following the GRI G4 standard that has come into use. The criteria used are banks that did not experience a loss, generated sustainability reports according to the GRI G4 standards, and were not delisted during the observation period. The data was then processed using the Statistical Package for Social Sciences (SPSS) ver 25.0 in performing the classical-assumption test, and Smart PLS v. 3 for conducting the effect-test and path-analysis.

The operational variables and instruments used in this study are as follows:
Table 1 Operational Variables in This Study

\begin{tabular}{|l|l|}
\hline \multicolumn{1}{|c|}{ Variable } & \multicolumn{1}{c|}{ Proxy / Formula } \\
\hline Financial Performance & ROA $=\frac{\text { Net Income }}{\text { Total Assets }}$ \\
\hline Intellectual Capital & $\begin{array}{l}\text { VAIC }=\text { VACE + VAHU + } \\
\text { STVS }\end{array}$ \\
\hline $\begin{array}{l}\text { Corporate Social } \\
\text { Responsible }\end{array}$ & CSRIj $=\frac{\sum X i j}{n j}$ \\
\hline Firm Value & Tobin's $Q=\frac{\text { MVE }+ \text { Debt }}{\text { Total Assets }}$ \\
\hline
\end{tabular}

Legends: ROA = Return-on-Assets; VAIC = Value-Added Intellectual Coefficient; (VACE) Value-Added Capital Employed; VAHU = Value-Added Human Capital; STVA $=$ Structural Capital Value-Added; MVE : Market Value of Equity

Corporate Social Responsibility using the Corporate Social Responsibility Index (CSRI) is based on GRI G4 standards and banking-specific standards to measure the disclosures related to social responsibility carried out by companies regarding the environment, social, and economy that are reported in a Sustainability Report [30]. The GRI G4 used is 'Core Option', which amounts to 33 items and Standard Financial Services Sector Disclosures totaling 31 items, so that there are 64 items as indicators in CSRI measurements, and the last is firm value, which is measured using Tobin's Q formula.

\section{RESULTS, CONCLUSIONS, DISCUSSIONS AND IMPLICATIONS}

There are 45 listed banking industry populations in the observation period, however, 12 companies issued sustainability reports based on GRI G4, 12 companies were delisted, 2 companies suffered losses, and 3 companies did not issue sustainability reports in the years during the observation period. Thus, the number of samples used in this study was 30 samples.

\subsection{Results}

The results of the 30 samples were subjected to a classicalassumption test before the regression-test and pathanalysis were conducted. The classical-assumption test results were carried out as follows:

Table 2 The Results of Preliminary Tests

\begin{tabular}{|c|c|c|}
\hline \multicolumn{3}{|c|}{ Normality Test } \\
\hline $\begin{array}{l}\text { Asymp. Sig. } \\
\text { (2-tailed) }\end{array}$ & $\begin{array}{l}\text { Unstandardized } \\
\text { Residual: } 0.200\end{array}$ & $\begin{array}{l}0.200>0.05 \\
\text { Normal }\end{array}$ \\
\hline \multicolumn{3}{|c|}{ Heteroscedasticity Test } \\
\hline $\begin{array}{l}\text { Financial } \\
\text { Performance }\end{array}$ & Sig : 0.053 & $\begin{array}{l}0.053>0.05 \\
\text { No } \\
\text { Heteroscedasticity }\end{array}$ \\
\hline $\begin{array}{l}\text { Intellectual } \\
\text { Capital }\end{array}$ & Sig : 0.781 & $\begin{array}{l}0.781>0.05 \\
\text { No }\end{array}$ \\
\hline
\end{tabular}




\begin{tabular}{|c|c|c|c|}
\hline & \multirow{2}{*}{\multicolumn{2}{|c|}{ Sig : 0.150}} & Heteroscedasticity \\
\hline$\overline{\mathrm{CSR}}$ & & & $\begin{array}{l}0.150>0.05 \\
\text { No } \\
\text { Heteroscedasticity }\end{array}$ \\
\hline \multicolumn{4}{|c|}{ Autocorrelation Test } \\
\hline $\begin{array}{l}\text { Asymp. Sig. } \\
\text { (2-tailed) }\end{array}$ & \multicolumn{2}{|c|}{$\begin{array}{l}\text { Unstandardized } \\
\text { Residual : } 0.853 \\
\end{array}$} & $\begin{array}{l}0.853>0.5 \\
\text { No autocorrelation }\end{array}$ \\
\hline \multicolumn{4}{|c|}{ Multicollinearity Test } \\
\hline $\begin{array}{l}\text { Financial } \\
\text { Performance }\end{array}$ & $\begin{array}{c}\text { Tolerance } \\
: 0.999\end{array}$ & $\begin{array}{l}\text { VIF : } \\
1.001\end{array}$ & $\begin{array}{l}\text { Tol. } 0.999>0.1 \& \\
\text { VIF } 1.001<10 \\
\text { Qualify for the } \\
\text { regression test }\end{array}$ \\
\hline $\begin{array}{l}\text { Intellectual } \\
\text { Capital }\end{array}$ & $\begin{array}{c}\text { Tolerance } \\
: 0.979\end{array}$ & $\begin{array}{l}\text { VIF : } \\
1.021\end{array}$ & $\begin{array}{l}\text { Tol. } 0.979>0.1 \& \\
\text { VIF } 1.021<10 \\
\text { Qualify for the } \\
\text { regression test }\end{array}$ \\
\hline CSR & $\begin{array}{c}\text { Tolerance } \\
: 0.979\end{array}$ & $\begin{array}{l}\text { VIF : } \\
1.021\end{array}$ & $\begin{array}{l}\text { Tol. } 0.979>0.1 \& \\
\text { VIF } 1.021<10 \\
\text { Qualify for the } \\
\text { regression test }\end{array}$ \\
\hline
\end{tabular}

Source: Data Processing by SPSS v.25

Meanwhile, the results of the regression test and path analysis coefficient are displayed as follows:

Table 3 The Results of Regression Test

\begin{tabular}{|l|c|c|c|}
\hline \multicolumn{1}{|c|}{ Variables } & t-Stat & $\begin{array}{c}\text { p- } \\
\text { Values }\end{array}$ & Decisions \\
\hline CSR on FV & 0.546 & 0.585 & Rejected \\
\hline IC on FV & $2.614^{*}$ & 0.009 & Accepted \\
\hline FP on FV & $2.721^{*}$ & 0.007 & Accepted \\
\hline IC on CSR & 0.244 & 0.808 & Rejected \\
\hline FP on CSR & 1.690 & 0.092 & Rejected \\
\hline
\end{tabular}

Legend: FP = Financial Performance; IC $=$ Intellectual Capital; CSR = Corporate Social Responsibility; FV : Firm Value. *) t-test > $1.96(5 \%)$

Source: Data Processing by Smart PLS v.3

From the results above, Intellectual Capital and Financial Performance directly have a significant and positive influence on firm value, but not on CSR. Likewise, CSR does not have a significant effect on firm value even though it has a positive direction. The insignificance of CSR towards firm value is probably due to the CSR activities that have not had an impact on environmental sustainability and social life where companies carry out CSR. Indeed, this industry does not have a direct relationship to the use of natural resources which can damage the environment and social life. Based on this reason, investors pay less attention to CSR issues in this industry so that there is an insignificant effect of CSR on firm value.

\subsection{Conclusions}

Based on these results, it can be ignored that CSR serves as a mediating variable in the relationship between financial performance and intellectual capital in the banking industry, which is not a problem for the market that shapes corporate value. The involvement of internal stakeholders, namely human capital in activities has not become a determinant in sustainable business. This is because this industry uses natural resources directly so that CSR activities are only carried out as obligations.

\subsection{Discussions \& Implications}

Increased understanding of and the role of human capital must be enhanced in CSR activities which are not only related to social activities of the community, but also to the environment, such as reducing usage, electricity, electronic waste, and other natural resources. On the order side, the government's objective through the FSA, which obliges and reports on their CSR activities, is to pay attention to lending to companies that do not destroy nature and resources to create sustainable finance, banks should also be able to protect the resources, especially the community and human capital as internal stakeholders. With this research, it is hoped that the implementation of CSR is not only about doing obligations but also pay attention to its impact. Support from the board of directors and commissioners, especially independent directors and commissioners, is needed. It is hoped that the increase in CSR will be the quality of qualitative information that can increase the company's value in the market.

\section{REFERENCES}

[1] Epstein, \& M. Freedman, M. 1994). Social Disclosure and Individual Investor. Accounting, Auditing \& Accountability Journal,1994 7(4), 94-109.

[2] Undang-Undang Republik Indonesia Nomor 40 Tahun 2007 Tentang Tanggung Jawab Sosial Dan Lingkungan

[3] Peraturan Otoritas Jasa Keuangan No. 51/POJK.03/2017 Tentang Penerapan Keuangan Berkelanjutan Bagi Lembaga Jasa Keuangan, Emiten dan Perusahaan Publik.

[4] S. Anwar, S. Haderani, G. Pagalung. Pengaruh Pengungkapan Corporate Social Responsibility terhadap Kinerja Keuangan Perusahaan dan Harga Saham, 2010. 1-8.

[5] F. H. A.Rauf, F. M.Khalid, N. A. Mustafa, N. F. Isa, M., J. N. J. Johari, G.A. Krishnan, G. A. L. The Effect of Intellectual Capital on Value Creation: Malaysian Evidence. Global Business and Management Research: An International Journal, 2018. 10(3), 160-169. 
[6] Bhat, K. U., Chen, Y., Jebran, K., \& Bhutto, N. A. (2018). Corporate Governance And Firm Value A Comparative Analysis Of State And Non-State Owned Companies In The Context Of Pakistan. Corporate Governance, 18(6), 1196-1206.

[7] Hermawan, S., \& Maf'ulah, A. N. (2014). Pengaruh kinerja keuangan terhadap nilai perusahaan dengan pengungkapan corporate social responsibility sebagai variabel pemoderasi. Jurnal Dinamika Akuntansi, 6(2), 103-118.

[8] Ghozali, A., \& Hatane, S. (2014) Pengaruh Intellectual Capital Terhadap Kinerja Keuangan dan Nilai Perusahaan Khususnya di Industri Keuangan dan Industri Pertambangan Yang Terdaftar di Bursa Efek Indonesia Tahun 2008 - 2012. (002), Akuntansi Bisnis Universitas Kristen Petra, Surabaya.

[9] D. Asmawanti, I.O.Wijayanti. Intellectual capital and corporate Social responsibility in banking industries in Indonesia. Journal of Economics, Business, and Accountancy Ventura, 2017,20(2), 191 200.

[10] S. Aslam, M. Ahmad, S.Amin, M. Usman, S. Arif. The Impact Of Corporate Governance And Intellectual Capital On Firm's Performance And Corporate Social Responsibility Disclosure. Pakistan and Social Sciences (PJCSS), 2018, 12(1), 283-308.

[11] Hermawana. M.S., dan Mulyawan. S.G. 2014. Profitability And Corporate Social Responsibility: An Analysis Of Indonesia's Listed Company. Asia Pacific Journal of Accounting and Finance Volume 3 (1), December 2014.

[12] Ching.H.Y, Gerab. F, dan Toste.T.H. 2017.The Quality of Sustainability Reports and Corporate Financial Performance: Evidence From Brazilian Listed Companies. SAGE Open April-June 2017: 1-9. 2017 DOI: $10.1177 / 2158244017712027$

journals.sagepub.com/home/sgo.

[13] Uwuigbe et al. 2017.Sustainability Reporting And Firm Performance: A Bi-Directional Approach. Academy of Strategic Management Journal Volume 17, Issue 3, 20181 1939-6104-17-3-222.

[14] H.Lukman. R. Suhendah, J. Evan. Rousilita Suhendah, Jesica Evan. Analysis of Corporate Social Responsibility and Environmental Performance Report Forward Financial Performance on Proper Ranking Companies in Indonesia. Advances in Economics,
Business and Management Research, volume 151. Proceedings of the International Conference on Management, Accounting, and Economy (ICMAE 2020). 2020 P. 274-2.79.

[15] R.D. Retno, D. Priantinah, Pengaruh Good Corporate Governance dan Pengungkapan Corporate Social Responsibility terhadap Nilai Perusahaan. Jurnal Nominal, 2012, 1(1), 84-103.

[16] R. E. Freeman (2004, A Stakeholder Theory of Modern Corporations. Ethical Theory and Business, 7th ed. 2004.

[17] E. Widarjo. Pengaruh Modal Intelektual dan Pengungkapan Modal Intelektual pada nilai perusahaan yang melakukan intial public offering. Jurnal Akuntansi dan Keuangan Indonesia, 2011. 8(2), 157-170.

[18] V. Murale, R. Jayaraj, Ashrafali. Impact of intellectual capital on firm performance: A resourcebased view using VAIC Approach. International Journal of Business Management, Economics and Information Technology, 2010. 2(2), 283-292.

[19] R. Amit, R, P. Shoemaker, Strategic assets, and organizational rent. Strategic Management Journal, 1993, 14(1), 33-46.

[20] A. Pulic. Measuring the Performance of Intellectual Potential in Knowledge Economy. Paper presented at the 2nd McMaster Word Congress on Measuring and Managing Intellectual Capital by the Austrian Team for Intellectual Potential. 1998.

[21] B. Solikhah, , A. Rohman, W. Meiranto. Implikasi Intellectual Capital Terhadap Financial Performance, Growth, dan Market Value: Studi Empiris Dengan Pendekatan Simplistic Specification. Paper dipresentasikan pada acara Simposium Nasional Akuntansi XIII, Purwokerto. 2010.

[22] R.H. Whiting, J.C. Miller. Voluntary Disclosure Of Intellectual Capital In New Zealand Annual Reports And The Hidden Value. Journal of Human Resource Costing \& Accounting, 2008,12(1), 26-50.

[23] W. Rodgers. Problems and resolutions to future knowledge-based assets reporting. Journal of Intellectual Capital, 2007, 8(2), 205-215. 
[24] H.L.Sutriningsih, A. Rifa. Kinerja Keuangan Memediasi Pengaruh Corporate Social Responsibility dan Struktur Modal Terhadap Nilai Perusahaan. EJurnal Akuntansi Universitas Udayana, 2019, 21(1), 764-791.

[25] R. Gultom, S.W. Wijaya, Agustina. Analisis Faktor-Faktor Yang Mempengaruhi Nilai Perusahaan Pada Perusahaan Farmasi Di Bursa Efek Indonesia. Jurnal Wira Ekonomi Mikroskil, 2013, 3(1), 51-60.

[26] S. Husnan, Manajemen Keuangan: Teori dan Penerapan (Kepututsan Jangka Panjang). BPFEYogyakarta. 2012.

[27] T.K. Pertiwi, F.M. I. Pratama. Pengaruh Kinerja Keuangan, Good Corporate Governance Terhadap Nilai Perusahaan Food and Beverage, Jurnal Manajemen dan Kewirausahaan, 201214 (2) 118-127.

[28] K.B.S. Utama, I.P.Yadnya. Pengaruh Kinerja Keuangan Terhadap Nilai Perusahaan dengan Pengungkapan CSR dan GCG sebagai Variabel Pedomerasi. E-Jurnal Manajemen Unud, 2016, 5(5), 2665-2695.

[29] L. Edvinsson, M. Malone. Intellectual capital: Realizing your company's true value by finding its hidden brainpower. Harper Business, New York, 1st Edition.1997.

[30] M. Khalique, M, N. Bontis, J. A.N.Shaari, A. H.M Isa, Intellectual capital in small and medium enterprises in Pakistan, Journal of Intellectual Capital, 2015, 16(1), 224-238.

[31] S.Hosomi. Study on the relation between intellectual capital and corporate performance for the management of organisational capital. Research Paper Nr. 120 University of Oxford, UK Skope, 11-47. 2014.

[32] J.Jurczak. Intellectual capital measurement methods. Economics and Organization of Enterprise, 2008,1(1), 37-45.

[33] N.Bontis. Managing organizational knowledge by diagnosing intellectual capital: Framing and advancing the state of the field. International Journal of Technology Management, 1999,18(5-8), 433-463.

[34] E.Pauente, J. Sabate, J. Garcia. Firm social performance (CSP) and firm reputation: Two interwoven perspectives. Firm Reputation Review, 2207, 10(1), 60-72.

[35] Sabrina, H. Lukman. Pengaruh Sustainability Report Terhadap Kinerja Keuangan Perusahaan Perbankan. Jurnal Multiparadigma Akuntansi, 1(2), 477-486.

[36] Isnalita, M. Narsa. CSR Disclosure, Customer Loyalty, and Firm Values (Study at Mining Company Listed in Indonesia Stock Exchange). Asian Journal of Accounting Research,2017, 2(2), 8-14.

[37] M. Zaid, \& A. Nasiri. (2018). The Effects of Firm Charasteristics on Corporate Social Responsibility Disclosure: Evidence from Palestine. Research Journal of Finance and Accounting, 9(13), 46-53. 